\title{
The Importance of the Convergence of Legal Cultures for Modern Trends of Integration
}

\author{
Hanna Duszka-Jakimko \\ The Institute of the Theory and Philosophy of Law, \\ University of Opole, Poland \\ Faculty of Law and Administration
}

\begin{abstract}
Reflections on the importance of cultural convergence and integration in the European countries of the region are still present in the social, economic and legal discourse. Converging trends, in most general terms, mean strengthening, consolidation and merging international political, economic and cultural cooperation. A contribution to this is given by processes widely discussed in the literature like globalization, economic liberalization and political, ideological and moral pluralism. The phenomenon of convergence applies to law as such. The above mentioned factors are fostering the convergence of law. However, one can indicate conditions shaping legal integration in a specific way. An adhesive joining the European legal culture tends to be a common legal tradition of states of the relevant cultural area, constitutional tradition, ethical values - humanity, freedom, justice and equality - defining the legal thinking and interpretation of the law. These considerations aim to illustrate the importance of the convergence of legal cultures to seek answers about the role and importance of law and changes in the way of understanding of the law within globalization and integration processes. For this purpose, the concept of globalization will be reconstructed as well as the idea of integration, culture and legal culture, and then described the impact of converging trends on the processes of creation, interpretation and application of the law.
\end{abstract}

Keywords: Convergence, Legal Cultures, Modern Trends, Integration

\section{Introduction}

A theorem of contemporary, multifaceted integration trends which indicate the establishment, consolidation and integration of the international cooperation of legal entities within the political and economic field, and which determine the areas of cooperation in many fields of social and economic life, is a truism. Something which is primarily affected by the processes of globalization ${ }^{1}$ which receive a broad literary coverage, economic and political liberalization, related geopolitical situation, and ideological and moral pluralism². The phenomenon of integration which contributes to cultural, social, and civil changes also applies to law. The elements indicated above certainly belong to a group of factors which support legal integration; However, there are certain conditions, specifically legal, which shape the institutional legal integration, in both regional (e. g. European) and international aspects. The unifying factors certainly include a common legal tradition in the countries from certain cultural area, constitutional tradition, the idea of convergence of cultures, and ethical values such as humanity, freedom, justice and equality. The problem of the institutional dimension of legal integration has already been widely discussed in literature, with focus on the analyses of the integration processes which function for years worldwide, and the ones closer to us, in Europe which relate to the development of European Union ${ }^{3}$. However, despite the currently

\footnotetext{
${ }_{1}$ See i.a. Integration and Globalization from the Perspective of the Philosophy of Law by A. Bator, W. Gromski, S. Kaźmierczyk, A. Kozak, [in: The Philosophy of Law and Globalism, ed. J. Stelmach, Kraków 2003, pp. 9-26]; Globalization and Jurisdiction by J. Guść, K. Łokucijewski, . On the Impact of Globalization on the Scale of Law-making in the Liberal Democratic State, [in: The Philosophy of Law to ..., pp. 27- 37;], The Current dispute about the Concept of Law by T. Kozlowski, [in: Legal and Theoretical issues with European Integration, ed. L. Leszczynski, Lublin 2004, p. 12-32]; idem, The Philosophicality of law as the law de-nationalized as per the expertise of Andrew Stelmachowski [in: The Law in the Era of Globalization, materials from the Xlth Conference of the Faculty of Law, University of Warsaw, Warsaw 2010, pp. 26-34].

2 M. Szyszkowska, Prawo jako czynnik kształtujący nową świadomość obywateli w dobie globalizacji,[transl. Law as a Factor which shapes a new awareness of citizens in the age of globalization] [In:] Prawo w dobie globalizacji [transl.The Law in the Era of Globalization] materials for XI Conference of the Faculty of Law, University of Warsaw, Warsaw 2010, p. 7.

3 In literature, the idea of integration has wide possibilities of interpretation, not only as relating to EU, but also to the Council of Europe as a coordinating body which defines common standards; see.
} 
observable changes in the way the law is created and applied, and bases of thinking about the law, seeking the legal grounds for integration still seems to be a current issue. Such explorations appear to be justified by the questions about the role of law in the light of globalization and integration processes, about the prospect of changes in the attitudes towards the nature of law ${ }^{1}$, as well as about the bases for the development of a common cultural code.

II.

In the deliberations concerning legal integration in the European space, what is specifically analyzed is the dogmatic perspective; that is the emphasis on the development and functioning of legal institutions which are the product of a close and enhanced cooperation between the Member States of the European Union. The process of integration is accomplished through the evaluation of methods of approximation and codification of law (among the methods of European integration, the following are distinguished: mutual recognition, coordination, harmonization, substitution ${ }^{2}$ ), which applies to the creation of common institutions and legal regulations in specific areas (pertaining mostly to the economic and social integration, as well as to new areas such as the Internet and global business communication), to the universalization and the development of common legal principles and methods of interpretation for authorities enforcing the law (claritas doctrine, common interpretation directives and types of legal argumentation), to the formulas of law application (the classical model of law application, related to the state of justice, and a post-classical one, identified with the principle of fair trial, the legislation of adequate guarantees, and, other than adjudicate ${ }^{3}$, modes of resolving legal issues), to creating a system of basic human rights and their protection, and to the development of structural and institutional principles of functioning of the Union. Obviously, it is easy to identify those branches of law in which the integration develops the fullest and most intensively, as, for instance, in business law (hence, it is emphasized that integration in Europe means primarily the creation of "economic community"), labor law and environmental law4.

However, the institutional signs of integration indicated above enforce the search for internal basics for the "community of law ${ }^{5 "}$. The study of integration processes cannot be limited only to concepts, rules or institutions related to it. Therefore, next to the formal and dogmatic methods or naturalistic, typical for legal positivism, way of recognition of the law, it is necessary to adopt an attitude which considers law as the object of communication and the object of culture. It is relevant to the processes of integration, to see the concept of law "in the light of culture," thought, as noted by M. Zirk-Sadowski, understanding of the law as a cultural object, as a group of certain meanings ${ }^{6}$ upon which the order in the integration process and the creation of a common "code of legal culture ${ }^{7 "}$ and "common meanings and symbols" 8 depend. The image

Z. Brodecki, Filozofia prawa europejskiego [transl. The Philosophy of European Law], [In:] Integracja europejska. Wprowadzenie, [transl. European Integration. Introduction] ed. M. Perkowski, Warszawa 2002, p.16.

${ }_{1}$ About the necessity of changing the positivist paradigm of the conception of law in connection with the development of European law see. T. Giaro, Dogmatyka i historia prawa w dobie globalizacji. Nowe rozdanie kart, [transl. Dogma and the history of law in the age of globalization, the new deal] [In:] Prawo w dobie..., p. 39-50; T. Kozłowski, Spór o obecne pojęcie...[transl. The dispute over the present idea of...]; p.13, also J. Winczorek, Socjologia prawa a integracja europejska. O pożytkach z pewnej teorii [transl. Sociology of law and European integration. About the benefits coming from a certain theory]. [In:] Teoretycznoprawne problemy integracji..., pp. 38-39 [transl. Theoretical and legal issues with integration].

2 For more information on the methods of integration, see. i.a. Z. Brodecki, Prawo europejskiej integracji, Warszawa 2001, p. 92-96; also E. Dynia, Integracja europejska. Zarys problematyki, [transl. European Integration, an outline], Warszawa 2003; J. Ruszkowski, E. Górnicz, M. Żurek, Leksykon integracji europejskiej, Warszawa 1998 [transl. Lexicon of European Integration].

${ }^{3}$ See. more in L. Morawski, L. Morawski, Główne problemy współczesnej filozofii prawa. Prawo w toku przemian, Warszawa 2003, ch. VII. [transl. The Main Problems of Contemporary Philosophy of Law. The Law in the course of Transition]

${ }^{4}$ See more in S. Hoogmoed, Integration of Europe, International Institute of Interdisciplinary Integration 1995.

5 Z. Brodecki, Prawo integracji w Europie, Warszawa 2008, p. 21.

${ }^{6}$ M. Zirk-Sadowski, Uczestniczenie prawników w kulturze, „Państwo i Prawo”, 2002, no 9, p. 11.[transl. Emploees' participation in culture, "Country and Law"]

${ }^{7}$ Z. Brodecki, Prawo integracji w Europie.., p. 23. For more information on the notion, characteristics of legal culture and its influence on legal awareness and legal basis please check i.a. A. Gryniuk, Próba rozstrzygnięcia sporu o status kultury prawnej, [In:] Ze sztandarem przez świat, ed. R. Tokarczyk, K. Motyka, Kraków 2002, s.81- 87; K. Pałecki, O pojęciu kultury prawnej, „Studia Socjologiczne”, 1972, b.2, p. 205- 224; this same O użyteczności pojęcia kultura prawna, „Państwo i Prawo” 1974, b. 2, p. 65-75; M. Zirk-Sadowski, Prawo a kultura, Notebooks of science. U Ł, Nauki Humanistyczno-Społeczne, series I, book. 19, 1977, pp. 29-42;

8 M. Zirk-Sadowski, Pozytywizm prawniczy a filozoficzna opozycja podmiotu i przedmiotu poznania [transl. Legal positivism and philosophical opposition of subject and object of knowledge], [In:] Studia z filozofii prawa, ed. J. Stelmach, Kraków 2001, s. 95; the same 
of the code of culture consists of factors such as the tradition of legal culture of societies which participate in the integration process, their legal traditions, concepts, values, as well as the law itself which is, in fact, a reflection of that culture, the normative patterns of behavior related to it and values associated with socially accepted standards, and the legal awareness of social actors and their attitudes towards the law.

The legal culture, as noted by A. Gryniuk, is expressed in recognizing its products, the values, norms, ideals, as the ones which play a leading role in the life of given community ${ }^{1}$. In the case of the integration processes, these cultural products should include patterns (specific, native, primates ${ }^{2}$ ) common to legal cultures and their traditions. The core of each legal culture consists of: specificity of the historical development of the law, views on its nature, philosophical orientations dominant in a given area, concepts law sources and its development, principles of law, style in which legal concepts are used, methodology, methods of reasoning and argumentation, style of justifications for judgments and decisions, forms of documents ${ }^{3}$. And although legal norms may be changed on daily basis, their creation and use will still depend on continued immutable components of legal culture. The concepts, institutions and procedures created in the process of rule integration, will therefore be a reflection of national tradition and legal culture ${ }^{4}$. In the perspective of European integration, it is the penetration of cultural traditions - common law and civil law ${ }^{5}$, the heritage of the former of which is reflected in the procedural sphere, while cultural elements of positive law are often present in substantive law (in private law as the lex contractus mainly). It is, in other words, a transfer of values and behaviors which shape, based on law, mentalities and legal "habits". The clash of traditions of Roman-Germanic and Anglo-American cultures performs certainly cognitive, law-making, interpretation and unification ${ }^{6}$ functions. And although in science the notion of culture encompasses a plethora of concepts ${ }^{7}$ (as noted by K. Pałecki: "legal culture has so many meanings, as many authors mention it"8), in general, in the context of anthropological approach, the term "culture" refers to a set of human behaviors which follow certain patters (rules, norms); the world of culture is therefore a world which blooms from actual human creations, from material and spiritual human activity ${ }^{9}$. It is the actions of individuals that create or promote certain patterns (norm, rule). As noted by K. Pałecki, these behaviors are transmitted "synchronously (i. e. within one generation) as well as diachronically (i. e. from generation to generation); they are relatively stable and relatively common. "10 Following this assumption, law is a part of culture ${ }^{11}$,

Instytucjonalny i kulturowy wymiar integracji prawnej, [In:] Zmiany społeczne a zmiany w prawie. Aksjologia, konstytucja, integracja europejska, red. L. Leszczyński, Lublin 1999, p. 36. [transl. This same Institutional and Cultural dimension of Legal Integration, [In:Social Changes and Changes in the Law.Axiology, Constitution, European Integration, ed. L. Leszczynski, Lublin 1999, p. 36.]

${ }^{1}$ A. Gryniuk, Próba rozstrzygnięcia sporu o status kultury prawnej, [in:] Ze sztandarem przez świat, ed. R. Tokarczyk, K. Motyka, Kraków 2002, p. 83.

2 lbid.

${ }^{3}$ See more in I. Gołowska, „A mixed system of Law” [in: Legal System and Legal Order, ed. O. Bogucki, S. Czepita, Szczecin 2008, p.80]; A. Gryniuk, „An attempt to resolve the dispute over status” p. 86. [trans. I. Gołowska, Mieszany system prawa, [w:] System prawny a porządek prawny, red. O. Bogucki, S. Czepita, Szczecin 2008, s. 80; A. Gryniuk, Próba rozstrzygnięcia sporu o status..., s. 86. ]

${ }^{4}$ Compare L.S. Stadniczenko „The legal Culture” [in: Juridical dictionary of difficult words, Ed. by J. Boć, Wrocław 2015, pp. 199-200] [transl. L.S. Stadniczeńko, Kultura prawna, [in:] Prawniczy Słownik Wyrazów Trudnych, red. J. Boć, Wrocław 2005, s. 199-200.]

${ }^{5}$ More about the essence of the Anglo- Saxon law model and Continental law see M. Stępień, Systemowość prawa europejskiego, Poznań 2008, p. 45-58; R. Tokarczyk, Współczesne kultury prawne, Kraków 2001.

6 I. Gołowska, Mieszany system prawa..., p. 83.

7 Compare J. Pruszyński "The legal Culture - Cultural Heritage" [in: The Law of the XXI Century. The Memorial Book of The Institute of Law of PAN, Ed. By W. Czapliński, Warszawa 2006, p.670]. [transl. J. Pruszyński, Kultura-kultura prawna - dziedzictwo kultury, [w:] Prawo w XXI wieku. Księga pamiątkowa Instytutu Nauk Prawnych PAN, red. W. Czapliński, Warszawa 2006, s. 670].

${ }^{8}$ K. Pałecki, O użyteczności pojęcia kultura prawna, „Państwo i Prawo” 1974, b.2, p. 65.

${ }^{9}$ Comp. A. Gryniuk, Próba rozstrzygnięcia sporu..[transl. „An Attempt to Resolve the Dispute ."], p. 82; A. Kłoskowska, Kultura, [Culture] [In:] Encyklopedia socjologii, [transl. The Encyclopedia of Sociology], Warszawa 1999, p.105; J. Szczepański, Elementarne pojęcia socjologii, Warszawa 1970, p.78; M. Zirk-Sadowski, Prawo a kultura, „Zeszyty Naukowe Uniwersytetu Łódzkiego. Nauki Humanistyczno Społeczne", 1977, b.19, p. 36.

10 K. Pałecki, O użyteczności pojęcia kultura prawna...., p. 68.

11 More about the concept of culture and cultural concepts see M. Zirk-Sadowski, Prawo a kultura, „Zeszyty Naukowe Uniwersytetu Łódzkiego. Nauki Humanistyczno - Społeczne”, 1977, b.19; also: V. Gessner, Europäische Rechtskultur, [In:] Prawo w zmieniającym się społeczeństwie, Kraków 1992, p. 289-295; A. Bator, Wspólnota kulturowa jako element integracji prawa, [In:] Z zagadnień teorii i filozofii prawa. W poszukiwaniu podstaw prawa, ed. A. Sulikowski, Wrocław 2006, W. Gromski, Uwagi o podstawach europejskiej kultury prawnej, [In:] Z zagadnień teorii i filozofii prawa. W poszukiwaniu...., p.240-242; M. von Hoecke, European Legal Cultures in a context of Globalisation, [In:] Law and Legal Cultures in the 21 st Century. Diversity and Unity, ed. T. Gizbert-Studnicki, J. Stelmach, Warszawa 2007, p. 81; . R. Sobański, Kultura prawna Europy, „Studia Europejskie” 1998, no 3. 
because the standards contained therein belong to the general patterns which define the behaviors that make up a given culture. These are conveyed the same way as the other patterns of behavior (morals, customs, religion). The law has all the features typical to culture perceived as a category of "specifically social"1 ${ }^{1}$ phenomena, but also the differentia specifica relating to the patterns of creation and application of the law, largely identical in the countries of a given cultural area, to the meanings attributed to the basic legal concepts, and to the ways of realization of the decisions which are made in the process of law application². Legal culture is, thus, a rooted in tradition, common and inherited way a given society or its part understands the law with its role and function, it is how its norms and rules are shaped and how the law is applied and complied with ${ }^{3}$. In the anthropological approach, the concept of culture refers to a group of behavioral patterns and attitudes of individuals, and to the results of these behaviors and attitudes that express acceptance of social values ${ }^{4}$. Different views on legal culture are presented by K. Pałecki. In his definition of legal culture, it is not "a subset of symbolic practices which make up a culture," it is "the entirety of symbolic legal actions"5. Presentation of legal culture as "the entirety of actions" (instead of "the collection of patters"), according to K. Pałecki, allows to accept the "actual connections between these actions and culture and law"6. What must be remembered, however, is that legal culture is a fixed quality of certain, local environment. This is symbolic legal actions of a given collectivity in a certain time that realize patters of symbolic actions $^{7}$ contained in law. This is the reason why the term legal culture refers to the condition of applicable law, the development of legal thought, practice of law enforcement, evaluation and attitudes towards the law ${ }^{8}$. Legal culture is closely linked to widespread systems of values that determine the evolution of the legal system and social attitudes ${ }^{9}$. Both the Anglo-Saxon culture and the culture of civil law are a relatively structured systems of values of the primates and lawrelated ideas, which define the role and meaning of law in society, and which clarify the system of relations between citizens and the state ${ }^{10}$.

Therefore, as indicated by M. Borucka-Arctowa, the cultural factor can be treated as a "variable, which allows one to capture a certain dependence and to explain the course of specific processes (...) and to respond to the traditions and associations with the past, and more specifically, to norms and institutions originating from the past. "11

The consequences of the idea of convergence of legal cultures understood as bridging cultural differences, approximation of the law, and the concentration of unifying trends, can be observed in legal perspective which pertains to specific legal systems and to types, which in the case of European legal integration relate to the Anglo-Saxon and Roman-Germanic cultures. The idea of cultural convergence implies the dynamics of the convergence of legal cultures, their openness to change, interaction and interpenetration of cultural patterns, the removal of cultural and mental barriers. At the same time, the cultural convergence process should respect the cultural identity and the cultural core of societies. As K. Frieske stresses, the law and its variability, should be recognized in "the context of broader social processes, and more specifically, the processes of cultural change"12, and such is certainly the integration processes between different cultures and legal cultures. Nowadays, however, societies are exposed to seemingly contradictory trends, such as locality (related to national cultural distinctiveness and problems emerging at regional level) and globalization (and macro-economic and political problematics, as well as decisions which are taken at the international level) which will have a major influence on the complexity of the cultures. Cultural anthropologists, however, agree that in order for a culture to develop, it must increase the role of borrowings from other cultures. This should involve a constant state of tension (dynamics) between locality, tradition and integration processes, and openness of legal cultures to co-exist and use the achievements of other societies. Moreover, together with the evolution of cultural patterns, there is a change in normative beliefs relating to legal actions

\footnotetext{
${ }^{1}$ A. Gryniuk, Próba rozstrzygnięcia sporu..., p. 84.

2 K. Zeidler, Kultury prawne, [In:] Leksykon współczesnej teorii i filozofii prawa. 100 podstawowych pojęć, ed. J. Zajadło, Warszawa 2007, p.162. [transl. The Lexicon of Modern Theory and Philosophy of Law. 100 basic Concepts]

3 See more S. Russocki, Around the concepts of "political culture" and "legal culture", "The State and The Law"1981, b.3, p.44 [transl. S. Russocki, Wokół pojęć „kultura polityczna” i „kultura prawna”, „Państwo i Prawo” 1981, z.3, s. 44].

${ }^{4}$ K. Pałecki, O pojęciu kultury prawnej, „Studia Socjologiczne”, 1972, no 2, p. 215 and next.

5 lbid.

6 lbid.

7 lbid.

${ }^{8}$ Compare. A. Gryniuk, Próba rozstrzygnięcia sporu..., p. 84.

${ }_{9}^{9}$ K. Pałecki, O użyteczności pojęcia..., p. 66-67.

10 K. Zeidler, Kultury prawne, [In:] Leksykon współczesnej teorii ..., p.162.

11 M. Borucka-Arctowa, Problemy granic prawa, [In:] Problemy teorii i filozofii prawa, Lublin 1985, pp. 54-55.

12 K. Frieske, Socjologia prawa, Warszawa -Poznań 2001, p. 20.
} 
associated with the area of law-making (for example, one can specify introducing typically continental legal principles to the Anglo-Saxon legal culture: the primacy of the law, the increase of legislation and the increase of its role in the financial and administrative law, strengthening the role of parliament in the traditional areas of common law, derogations of precedent by legal act), with models of law application (in the continental law, there is a visible increase in the importance of judges activism and non-binding precedents as the "topos" of law affecting the interpretation of the law, introduction of the extrajudicial methods of settling disputes - ADR - Alternative Dispute Resolution to the continental legal systems, increase of the transparency of decision-making, and the clarity of rules and rule-making procedures), with lexical layer (introduction of the traditional continental terminology to local culture: e. g. "legal dogmatics" next to "legal doctrine," "travaux préparatoires" more than "legislative materiale"; inclusion of the new types of legal relationships, such as "leasing", "factoring" "franchises" to continental contract law, keeping English terminology, the mutual introduction of the Anglo-Saxon terminology to the language of statute law - jurisprudence, adjudicate and non-adjudicate mode of law enforcement and others).

Thus, the assertion that "the balance between the legislator, judge and the legal doctrine has become quite similar on both sides of the Channel"1 is appropriate for contemporary transformations. Adopting symbolic legal patterns of the AngloSaxon culture area may therefore influence the increase in numbers of behavior patterns within the continental culture, and vice versa. The convergence of ideas should result in the ability of using the heritage of other cultures, using achievements raised on existing patterns of local legal culture, but on top of it, using the exemplar belonging to a different legal culture.

Integration is an expression of an ideology upon which the European law is based. The law of Member States is the most important factor in the creation of the code of legal culture ${ }^{2}$ which "transmigrates" 3 legal concepts of freedom, equality, humanitarianism and justice, and praxeological values such as efficiency, into the philosophy of integration. In a European perspective, it is noted that because of the human being standing in the center of interest and because of individual's dignity considered to be the leading value, "the law is no longer derived either from God or from the country, or even from a given community, it is derived directly from an individual. "4 What attests to this view is the idea of a European personalism which indicates "the primacy of the a person as a subject, purpose and intellectual point of reference in the idea of law," ${ }^{5}$ as well as the system of human rights which is based upon the dignity of individuals, and which provides humans with advantage over the interests of the State.

European legal integration, which is based on the cultural core of the Member States ${ }^{6}$ - Greek philosophy of law, Roman law, common law and the Judeo-Christian ethics, all designed and well-established in the national legal cultures, on one hand, aims at creating its own cultural code, its own EU "legal tradition" ${ }^{7}$, on the other, is a measurable balance of homeostasis of national cultures, in a sense which meets the idea of convergence. Cultural changes, therefore, cause the transition from formalism, dogma and positivism towards materially-oriented and pragmatic approaches. ${ }^{8}$ Therefore, in the culture of European law, the following may be observed: 1) strengthening of the argumentative model of law application in difficult cases of law, 2) horizontal arrangement of the sources of law, 3) horizontal, contractual- network system of legal

\footnotetext{
1 lbid, p. 92.

2 Por. A. Kojder, Kultura prawna: problem demokracji i użyteczności pojęcia, [In:] Kultura prawna i dysfunkcjonalność prawa, [transl. „Legal culture: The problem with democracy and the usefulness of the concept", [in: Legal Culture and the Dysfunctionality of Law], Warszawa 1988, p. 191.

${ }^{3}$ I. Gołowska, Mieszany system prawa..., p. 86

${ }^{4}$ T. Kozłowski, Spór o obecne pojęcie..., p. 16; M. Sadowski, Godność człowieka i dobro wspólne jako fundament wartości europejskich. Propozycje katolickiej nauki społecznej, [In:] Aksjologiczne i praktyczne aspekty integracji europejskiej, ed. E. Kozerska i T. Scheffler, Wrocław 2007, p. 107. The idea of personalism normative grounds in the Treaty of Lisbon from 13.12 .2007 amending the Treaty on European Union and the Treaty establishing the European Community (OJ. EU 2007 / C 306/01), the full text in http://WWW.eur.lex.europa.eu

${ }^{5}$ S. Pilipiec, Autorytet prawa obowiązującego, [In:] System prawny a porządek prawny..., p. 271.

6 See R. Sobański, Kultura prawna Europy, „Studia Europejskie” 1998, no 3, p. 119; R. Tokarczyk, Kultura prawa europejskiego, „Studia Europejskie" 2000, no 1, p. 12.

${ }^{7}$ See M. von Hoecke, European Legal Cultures in a Context ..., p. 81-100.

${ }^{8}$ Comp. M.W. Hesselink, The New European Private Law: Essays on the Future of Private Law in Europe, Kluwer Law International 2002.
} 
relations, as well as the law treated as a cultural and communication (discursive) ${ }^{1}$ object characterized by the impact of the activity of legal entities under legal regulation on a system of normative expectations included in the applicable law, 4) blurring of boundaries between the classical disciplines of law (thus, becoming a culture of interdisciplinary law) ${ }^{2}, 5$ ) the activity of European courts closer to the tradition of common law, 6) the development of substantive law in the spirit of the continental tradition (harmonization of terminology), 7) the development of soft law.

European law is a reflection of the culture of many societies, which is why the European Union expresses, both in the Preamble and in Article 2 of the Treaty of Lisbon of 2007, the respect for Europe's cultural heritage, cultural diversity of the Member States and ensures constant development of Europe's cultural heritage ${ }^{3}$. These principles, being universal to the system of European law, base their axiological reasoning on the cultural core, assessments and values recognized in the Member States. These principles are a factor which limits the content of legal system standards, and respecting them is prescribed under the laws of the highest rank. ${ }^{4}$ Cultural core of the EU countries may therefore indicate some general directives on the orientation of EU law-making and may influence, in an indirect manner (without being formal validation rules), the content and form of the systemic character of the EU5: its structural and institutional rules, types law sources, the basis of application and exemption, the mode of law application, the relationship of the Member States with international and national law, for the creation of transnational norms binding regardless of nationality. It may also influence the creation of transnational norms which are binding regardless of nationality ${ }^{6}$. Ensuring the homogeneity of the very system in many respects, such as the uniformity of understanding, application and interpretation of European law, and universal compliance with it, is possible thanks to the principles which have emerged from the case law of the European Court of Justice and which are a part of the acquis communautaire, and with which each Member must comply: the primacy of Community law over national law, direct application of the direct effect of Community law in the national law of the Member States, subsidiarity and proportionality?.

III.

Integration processes, similarly to the processes of globalization, determine a process of enhancing the economic and political ties, influence the development of cross-border economic strategies, define and analyze current social and legal problems (decline in the social importance of family, increased gender equality, new definitions of marriage, migrations, computer crime problems), which are common to the Member States. Integration is the effect of the often mentioned exchange and transmittance of values and cultural elements. What is important in the integration process is for the idea of convergence to cover with its meaning both: the normative level of "ius" and "lex," and social "modernization" of existing practices, local "habits" of decision-making. However, integration, in parallel with the processes of approximation of law, brings tensions between national law orders and EU law, which is the result of a "strong (Kelsenowski) content relationships" ${ }^{8}$ of systems. Hence the view in the literature, that European law introduced into national legislation "remains an island

\footnotetext{
1 "The law is not presented as a ready object which is only recognizable by a lawyer, but as common meanings and symbols located in the discourse " - M. Zirk - Sadowski, „Legal positivism and philosophical opposition of the subject and object of knowledge”, [In: Studies in the Philosophy of law, ed. J. Stelmach, Kraków 2001, p.95.

[transl. „Prawo nie jest przedstawiane jako obiekt gotowy i jedynie rozpoznawalny przez prawnika, ale jako sytuowane w dyskursie wspólne sensy i symbole" - M. Zirk-Sadowski, Pozytywizm prawniczy a filozoficzna opozycja podmiotu i przedmiotu poznania, [w:] Studia z filozofii prawa, red. J. Stelmach, Kraków 2001, s. 95.]

2 See M.W. Hesselink, The New European Private Law: Essays on the Future of Private Law in Europe, Kluwer Law International 2002.

${ }^{3}$ See full text of the Treaty of Lisbon from 13.12.2007r. amending the Treaty on European Union and the Treaty establishing the European Community (OJ. EU 2007 / C 306/01), in: http://WWW.eur.lex.europa.eu

4 Z. Ziembiński, O stanowieniu i obowiązywaniu prawa. Zagadnienia podstawowe, Warszawa 1995, p. 90-91.

5 See more M. Stępień, Systemowość prawa europejskiego, Poznań 2008.

${ }^{6}$ M. von Hoecke, European Legal Cultures in a Context ..., pp. 81-100.

7 Zob. D. Kornobis - Romanowska, Sąd krajowy w prawie wspólnotowym [transl. „Domestic court in the Community law”], Kraków 2007, p. 17- 40; M. Masternak - Kubiak, Stosowanie prawa wspólnotowego (Unii Europejskiej) przez sądy polskie, [In:] Standardy konstytucyjne a problemy władzy sądowniczej i samorządu terytorialnego, Konferencja naukowa. Szczecin, 1 October 2007., [transl. Constitutional Standards and problems of the judiciary and local government, Scientific Conference] ed. O. Bogucki, J. Ciapała, P. Mijal, Szczecin 2008, pp. 62- 84 and judicature appointed in both publications.

${ }^{8} \mathrm{~A}$. Wróbel, As far as possibile - granice aktywizmu sędziowskiego czy alibi dla pasywizmu sędziowskiego, czyli o niektórych problemach wykładni prawa krajowego zgodnie z dyrektywami, [transl.„As far as possibile- limits of judicial activism or the alibi for the judicial passive
} 
among the traditional industries of national law that become inconsistent and non-uniform due to divergent rules which underlie the principles of national and European rules"1. The tensions, which come to light, relate to the reception of concepts, principles and legal institutions developed in the integration process, and unclear methods of interpretation of new regulations. In the area of administration, the excessive amount of administration system regulations increases may be observed, together with the increase of complex procedures, formal requirements and modes of decision making ${ }^{2}$. In some continental models, the "habit of instrumental treatment of the law", excessive formalization, informal influences and political pressure within the processes law application are still present. The effects of integration processes, which are difficult to assess unambiguously, also include the following: the progressive phenomenon of decentralization of state power, the growth of importance of regions and smooth cooperation between regions due to the removal of borders, the emergence of multiple centers of power, the comprehensive nature of local issues, and the difficulty with their management at the central level, and especially the decline of the authority of the nation state. Meanwhile, the new concepts and principles developed in the integration processes ought to be "translated into the local legal language" in the spirit of a pluralistic legal culture, so that they can be compatible, as much as possible, with legal culture of European societies, with attitudes, behaviors and values expressed in it.

European culture is a creation of " unification values imposed from above conflicting with local values cherished from bottom-up. The face of this culture determines the variety of attitudes, behaviors, socio-political and economic activities"3. Therefore, what types of foundations hatch to underlie legal culture is crucial to many processes taking place in law: its creation, interpretation and its application. In the era of permanent conflicts and ontological insecurity, we should especially remember about it.

attitude, that is about some problems with the interpretation of the domestic law according to directives"], [n:] Dyskrecjonalność w prawie, [transl. Discretionary in Law] ed. W. Staśkiewicz, T. Stawecki, Warszawa 2010, p. 106.

${ }^{1} \mathrm{M}$. von Hoecke notes that the period of the Middle Ages coped well with coexisting: canon law, local customary law and judges law due to the fact that they were interpreted and made more consistent, in the spirit of Roman law, see M. von Hoecke, European Legal Cultures in a Context ..., p. 96. It therefore seems that the modern and uniform rules, directives and methods of interpretation of law are the best remedy for issues with law-making, not only by the state, but by international bodies or organizations, compare i.a. A. Wróbel, As far as possible - "granice aktywizmu sędziowskiego ..., p. 108 and next.

${ }^{2}$ Interesting insights into the area of administrative actions related to the distribution of structural funds G. Skapska, Członkowstwo w Unii Europejskiej a kultura prawna. Refleksje oparte na wynikach badań nad rozdziałem funduszy strukturalnych, [transl. „Membership in the European Union and a legal culture. Reflections based on the results of studies on the distribution of structural funds] [In:] Dyskrecjonalność w prawie..., p.173-186.

${ }^{3}$ A. Breczko, Wpływ wartości chrześcijańskich na polską kulturę prawna i system prawa, [transl. „The influence of Christian values on the Polish legal culture and legal system"] [In:] Polska kultura prawna a proces integracji europejskiej, [transl. Polish legal culture and process of European integration] ed. S. Wronkowska, Kraków 2005, p. 269. 